\title{
EFECTELE PARTAJULUI ÎN NOUL COD CIVIL ROMÂN: O (R)EVOLUȚIE?
}

DOI: 10.24193 /SUBBiur.65(2020).4.12

Data publicării online:

16.03 .2021

\section{Dragoș ISACHE*}

Rezumat: Indiviziunea şi partajul aveau nevoie, în 2011, de o revigorare. Legiuitorul nu a făcut însă multe în această privință. A preluat din soluțiile jurisprudenței regulile privind administrarea indiviziunii (în sens larg) şi a construit, sumar, un regim legal, care, în niciun caz, nu poate satisface nevoile economice şi sociale ale coindivizarilor. Iar, posibilitatea încheierii unui contract de administrare rămâne într-un plan teoretic foarte îndepărtat de realitățile practice, unde un astfel de acord între coproprietari este inexistent. Se pare, totuşi, că atitudinea ostilă sau, oarecum, indiferentă, față de indiviziune încă mai există. Partajul - locul unde coproprietarii pun capăt indiviziunii - era al doilea punct unde se impuneau modificări. În 1864, legiuitorul a preluat efectul declarativ al partajului din dreptul francez, fără o analiză a consecințelor acestuia în plan economic. Familiile erau protejate, dar terții titulari ai unor drepturi reale asupra bunului comun erau sacrificați. Prin aceasta, indiviziunea era inatractivă şi nedorită. Legiuitorul din 2011 a identificat corect problema şi a oferit soluția - ce fusese adoptată de legiuitorul francez încă din 2006, chiar sub imperiul efectului declarativ - unei subrogații reale cu titlu particular: strămutarea garanției asupra bunului atribuit. Aceasta era suficientă pentru ca drepturile creditorilor garantați să fie menținute în toate cazurile. Prin aceasta, s-a asigurat şi dreptul fiecărui coproprietar de a dispune deplin şi eficient de dreptul său de coproprietate. Mai era nevoie de vreo schimbare în această privință? Se pare că nu. Cu toate acestea, legiuitorul din 2011 a decis, într-un mod neaşteptat, să renunțe la ficțiunea efectului declarativ. Ce a pus în loc? Efectul

* Doctorand UBB Cluj-Napoca, notar public în CNP Bacău și formator la Institutul notarial român, dragos isache@yahoo.com. 
translativ din dreptul roman? Nu! A imaginat un nou efect al partajului: efectul constitutiv. Şocul schimbării a fost receptat, în primul rând, în plan psihologic. În acel moment, ficțiunea efectului declarativ corespundea unei percepții psihologice potrivit căreia moștenitorii țineau bunurile direct de la defunct şi care era foarte bine consolidată după peste 140 ani de domnie. Așa cum ficțiunea efectului declarativ - în definitiv, o regulă născută conjuctural - generase numeroase dezbateri timp de câteva secole şi noul efect constitutiv al partajului a fost cu greu acceptat de practica notarială. Cauza? Temerea că noile consecințe ale efectului constitutiv se vor ciocni de regulile imperative ale regimului matrimonial comunitar, în cazul partajanților căsătoriți la data partajului. Într-adevăr, orice regim matrimonial comunitar este apt să absoarbă în masa bunurilor comune orice bunuri achiziționate sau dobândite cu titlu oneros de oricare dintre soți. Dar, dreptul de coproprietate al partajantului avea natura unui drept propriu. De altfel, întreg partajul avea loc pe tărâmul disputării unor drepturi proprii ale partajantului căsătorit. Doctrina s-a mărginit în a anunța introducerea efectului constitutiv, fără a construi o analiză amănunțită a efectelor acestuia şi în planul regimurilor matrimoniale. În ceea ce ne priveşte, am propus, la început, o analiză exhaustivă a consecințelor efectului translativ şi declarativ al partajului. Scopul a fost de a identifica natura juridică „firească” a partajului, adică constantele acestuia. Apoi, am demonstrat că efectul constitutiv trebuie interpretat şi aplicat unitar. În primul rând, partajul produce un efect înlocuitor. Cota parte este înlocuită de un drept de proprietate exclusivă. Este firesc astfel ca dreptul de proprietate exclusivă dobândit de fiecare partajant să aibă natura juridică a cotei-părți pe care o înlocuiește. În planul regimului matrimonial comunitar, este vorba de un bun propriu al partajantului căsătorit. Apoi, în cazul partajului cu sultă - care este apt să genereze cele mai multe controverse - am arătat că această modalitate de împărțeală nu degenerează partajul în două acte juridice: partaj şi vânzare. Nici partajantul care plăteşte sulta nu cumpără nimic, nici partajantul care primeşte sulta nu vinde nimic. Nici legiuitorul nu autorizează o astfel de idee, mai ales că acum ne aflăm pe tărâmul efectului constitutiv, unde este exclusă ideea unui schimb între partajanți. Efectul constitutiv al partajului cu sultă trebuie să fie aplicat unitar. Pentru partajantul căsătorit, aceasta nu constituie o achiziție cu titlu oneros. De altfel, obligația de plată a sultei reprezintă o obligație de a da care are natura juridică a unei obligații proprii. Numai executarea acesteia este făcută prin folosirea unor fonduri comune ale soților. Iar dobândirea majorată a bunului nu reprezintă o achiziție, ci este făcută în acelaşi spirit al efectului înlocuitor al cotei-părți.

Cuvinte cheie: partaj, efecte, efect constitutiv, efect declarativ. 


\title{
SETTLEMENT'S EFFECTS IN THE NEW ROMANIAN CIVIL CODE: A (R)EVOLUTION?
}

\begin{abstract}
Joint possession and settlement needed revival in 2011, yet the Legislator did not do much about it. It took from jurisprudence the regulations regarding joint possession (in the broad sense) and simply built a legal regime that in no way can satisfy the economic and social needs of joint holders. And the possibility to enter a management agreement remains in a very theoretical level that is far from practical reality, where such an agreement between joint owners does not exist. Settlement - the place where joint owners end their joint possession - was the second item that required modifications. In 1864, the Legislator took the declarative effect of settlement from French law without an analysis of its consequences on the economic level. Families were protected, but third parties, holders of real rights on the joint goods were sacrificed. This made settlement unattractive and unwanted. In 2011 the Legislator correctly identified the problem and offered the solution - that had been adopted by the French legislator since 2006, even under the rule of the declarative effect - a real subrogation with a particular title: resettlement of the guarantee on the assigned goods. This is sufficient for the rights of guaranteed creditors to be maintained in all cases. With this, the right of each joint owner to fully and efficiently use his joint ownership right was insured. Was another change in this area needed? Apparently not. Nevertheless the Legislator unexpectedly decided in 2011 to renounce the fiction of the declarative effect. What did it replace it with? The translative effect of Roman law? No! It imagined a new effect of settlement: the constitutive effect. The shock of the change was mainly felt psychologically. At that time, the fiction of the declarative effect corresponded to a psychological perception according to which the heir held the goods directly from the decreased, perception that was well grounded after more than 140 years of existence. Just as the fiction of the declarative effect - in fact a rule born out of conjunction -generated numerous debates over centuries, the new constitutive effect of settlement was had to accept in notary practice. The cause? The fear that the new consequences of the constitutive effect will conflict with the imperative rules of the community of goods in the case of settlement parties who were married on the settlement date. Indeed, any community matrimony regime is able to absorb in the settlement estate any goods purchased or obtained with onerous title by any of the spouses. But, the joint ownership right of settlement was that of an own goods. Moreover, the whole settlement was disputing own rights of the married settlement party. The doctrine limited itself to announcing the introduction of the constitutive effect without building a detailed analysis of its effects on the matrimony regimens. On our part, we suggested, at first an exhaustive analysis of the consequences of the translative and declarative effect of settlement. The purpose was to identify a 'natural' legal side of settlement that is its constants. Then we proved that the constitutive effect should be unitarily interpreted and applied. First of all, settlement produces a replacing effect. The share is replaced with an exclusive
\end{abstract}


ownership right. It is natural that the exclusive ownership right obtained by each settlement party has the legal nature of the share it replaces. In the marital community field, this is an own goods of the married settlement party. Then, in case of settlement with allowance - that is expected to generate even more controversies - we have shown that is division does not degenerate settlement in two legal acts: settlement and sale. The settlement party who paid the allowance does not purchase anything; the settlement party receiving the allowance does not sell anything. The Legislators does not authorize such an idea, especially now that we are on the realm of the constitutive effect, where the idea of an exchange between settlement parties is excluded. The constitutive effect of settlement with allowance should be unitarily applied. For the married settlement party, the payment of the allowance represents an obligation to give that has the legal nature of an own obligation. Only its execution is carried out by using common funds of the spouses. And the increase acquiring of the goods is not a purchase in itself as it is made in the same spirit of the replacement effect of the share.

Keywords: settlement, effects, constitutive effect, declarative effect. 


\section{Cuprins}

I. Introducere

II. Istoria efectelor partajului - de la efectul translativ la ficţiunea efectului declarativ

A. Parcursul istoric al naşterii ficţiunii efectului declarativ 422

1.Epoca romană

2.Epoca feudală franceză.

3.Codul civil Napoleon

B. Consecinţele efectului declarativ al partajului 431

C. Efectul declarativ şi efectul retroactiv al partajului 435

D. Actele asimilate partajului în sistemul efectului declarativ 437

III. Viziunea legiuitorului din 2011 439

A. Problema de rezolvat 439

B. Înlocuirea obiectului garanţiei 440

C. Problema altor drepturi constituite de un partajant în timpul indiviziunii

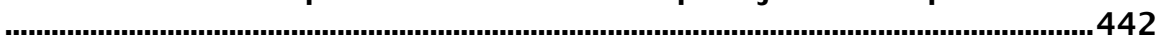

D. Problema modalităţilor care ar afecta dreptul de coproprietate 444

E. Efectul constitutiv al partajului - o naştere sui generis şi o înlocuire444

F. Natura juridică a bunurilor atribuite în cadrul partajului din perspectiva regimurilor matrimoniale comunitare. 451

I. Introducere

Orice demers legislativ - fie că este o noutate, fie că aduce cu sine o schimbare - corespunde unei nevoi. Este răspunsul legiuitorului la o necesitate socială, pe care vine să o încadreze normativ. Fie dă naştere unui raport juridic, fie îl corectează.

În ce consta nevoia de schimbare în materia partajului în anul 2011? Legiuitorul de la 1864 imaginase - prin imitație - din considerente de utilitate 
practică $^{1}$ - un efect al partajului diferit de ceea ce ar fi trebuit să fie efectul său natural, translativ - aşa cum acesta fusese anterior prezent în dreptul roman. Dar, efectul declarativ era departe de a fi perfect. El rezolva o problemă punctuală, dar - în alt plan - făcea (şi mai) inatractivă coproprietatea. În discuție, erau pe de-o parte interesele moştenitorilor - sau, liniştea familiilor - şi, pe de altă parte, interesele terţilor. Or, în 1864, interesele acestora din urmă au fost sacrificate. Cum efectul declarativ putea şterge dintr-o dată, ca un burete, actele consimțite de un moştenitor cu privire la cota sa parte sau cu privire la bunul comun, atenția legiuitorului era firesc să se fi îndreptat înspre identificarea unei soluții care să dea eficiență deplină dreptului de coproprietate. Un moştenitor care se vedea nevoit - de circumstanțele acestei stări - să se abțină să constituie drepturi reale asupra cotei sale succesorale avea două soluții: fie încerca, alături de ceilalți, să administreze bunurile comune, fie punea radical capăt indiviziunii, pentru a putea apoi dispune deplin de bunurile atribuite. Nici faptul că putea înstrăina cota sa indiviză nu trezea niciun interes pentru terţi, căci aceştia s-ar fi găsit în aceeaşi situație. Moştenitorii erau singurii cocontractanți viabili - într-un cuvânt, partajul sau restrângerea indiviziunii ! Nu putea, oare, să fie găsită o soluție intermediară, care să-i permită să dispună eficient de cota sa indiviză, fără ca terții să-şi vadă drepturile dobândite de la acesta nimicite la partaj şi fără ca acesta să fie împins atât de brutal spre ieşirea din indiviziune?

Din această perspectivă, intervenţia legiuitorului din 2011 era oarecum aşteptată.

În cele ce urmează, ne propunem să readucem din istorie efectul declarativ al partajului - care s-a instalat atât de firesc în lumea juridică timp

\footnotetext{
${ }^{1}$ Lupta împotriva fiscalităț ii feudale a rămas în istorie drept motivul principal pentru care a luat naştere - conjunctural - efectul declarativ.
} 
de secole - pentru a vedea, pe de-o parte, ce probleme rezolvase acesta la momentul naşterii ficțiunii şi, pe de altă parte, ce probleme lăsase nerezolvate şi cărora trebuia să li se găsească o soluție.

\section{Istoria efectelor partajului - de la efectul translativ la ficţiunea efectului declarativ}

Până în 2011, partajul - indiferent de sursa indiviziunii - a avut în dreptul românesc un efect declarativ drepturi. Acesta fusese imaginat fictiv încă din secolul al XVI-lea în legislația cutumiară franceză. Efectul declarativ a fost preluat apoi de legiuitorul francez în codificarea de la $1804^{2}$ şi de cel român de la 1864, contrar dispozițiilor din vechile legiuri privind efectul atributiv al partajului ${ }^{3}$. Altfel spus, partajul era declarativ de proprietate !

Dar, caracterul veritabil, adevărat şi logic al partajului, ale cărui baze fuseseră puse în dreptul roman, era de contract translativ de drepturi. Faptul că efectul declarativ reprezenta o ficţiune legală - un nonadevăr - precum şi temeiurile care au stat la baza instituirii acestei ficțiuni, erau îndeobşte cunoscute de doctrina românească4

${ }^{2}$ Codul civil belgian, care are drept model Codul Napoleon de la 1804, a menținut ficțiunea efectului declarativ al partajului şi în urma reformei dreptului succesoral din 31 iulie 2017.

3 N. Titulescu, Împărţeala moştenirilor, Bucureşti, Editura Librăriei Leon Alcalay, 1907, p. 29. Legiuirea Caragea nu conținea dispoziții privind efectul partajului, dar, în mod cert, acesta nu avea efect declarativ, căci o atare ficțiune ar fi trebuit să fie prevăzută expres (Partea a III, Cap.XIII). Codul Calimach statua că „împărțeala moştenirii are putere de cumpărare” (art.1092 - „Făcându-se împărțala moştenirei după pomenitul chip şi luând fieştecarele moştenitoriu partea cuvenită lui, se face desăvârşit proprietar a ei, socotindu-se ca şi un cumpărătoriu pentru că împărțala moştenirei are putere de cumpărare").

4 N. Titulescu, op.cit., 1907, p. 17; M. Eliescu, Transmisiunea şi împărţeala moştenirii în dreptul RSR, Editura Academiei RSR, Bucureşti, 1966, pp. 282-287; T. Carabaşiu, Partajul, Editura „Muntenia” Constanța, 1997, pp. 292-297. Alți autori nu au (mai) insistat asupra 
Cum şi de ce a ajuns partajul să aibă efect declarativ şi în ce consta efectul translativ? Un parcurs istoric ne va devoala istoria formării principiului efectului declarativ, dar şi natura juridică reală a contractului de partaj.

\section{A. Parcursul istoric al naşterii ficţiunii efectului declarativ}

\section{Epoca romană}

În dreptul roman, partajul era translativ de drepturi. Când un partajant devenea proprietar exclusiv asupra bunului indiviz ce îi fusese atribuit, se considera că ceilalți copartajanți îi cedaseră cotele lor indivize, respectiv că acesta le cedase cota sa indiviză asupra bunurilor care erau atribuite în exclusivitate acestora. În esenţă, între partajanţi avusese loc un schimb $^{5}$, iar schimbul era translativ de proprietate ${ }^{6}$. În final, dobândirea proprietății exclusive asupra bunului avea la bază două transmisiuni: pentru cota indiviză moştenită de partajant de la defunct, titlul era moştenirea, iar

faptului că efectul retroactiv ar reprezenta o ficțiune, Fr. Deak, Tratat de drept succesoral, Editura Actami, Bucureşti, 1999, p. 567.

5 A. Broussard, De l'effet translatif du partage en droit romain. De l'effet déclaratif du partage en droit français, teză pentru doctorat, Poitiers, 1866, p. 7. Atât timp cât durează indiviziunea, fiecare coindivizar are un drept de proprietate care se întinde asupra întregului bun. Partajul vine şi pune capăt acestei stări. Fiecare coindivizar primeşte un bun individual determinat corespunzător cotei indivize deținute. Să luăm un exemplu: doi coindivizari, A şi B dețin două imobile X şi Y. În urma partajului, imobilul X este atribuit lui A, iar imobilul Y este atribuit lui B. Dar, A nu avea dreptul decât la jumătate din imobilul X, iar B nu avea dreptul decât la jumătate din imobilul Y. Aceasta înseamnă că a achiziționat cealaltă jumătate. De la cine? De la celălalt coproprietar. Şi reciproc. Între A şi B a avut loc un schimb de părți indivize. Fiecare a transmis şi fiecare a primit. Aceasta este natura juridică reală a partajului: de schimb.

6 St. Liégeard, De l'origine, de l'esprit et des cas d'application de la maxime Le partage est déclaratif de propriété, Paris, 1855, p. 4; F. Laurent, Principes de droit civil français, ediția a V-a, 1893, Bruxelles/Paris, tom X, p. 410. 
pentru cota indiviză primită de la ceilalți partajanți, titlul era partajul, cu efect translativ.

Din natura translativă de drepturi a partajului rezultau două consecințe: partajanții trebuia să aibă capacitatea de a dispune pentru a realiza un partaj şi îşi datorau garanția pentru evicțiune asemănător vânzării sau schimbului7. Garanția pentru evicţiune urmărea însă un scop particular în cazul partajului: menţinerea egalității dintre partajanți. Garanția pentru evicțiune nu era de esența partajului. Ea putea fi înlăturată de partajanți. De asemenea, partajantul care cunoştea la data partajului cauza evicţiunii şi nu stipulase garanția în contract, nu o putea pretinde apoi ${ }^{8}$. Având efect translativ, partajul constituia just titlu, care stătea la baza invocării uzucapiunii.

Evident că efectul translativ avea consecințe importante cu privire la actele de dispoziție pe care unul dintre coproprietari le-ar fi încheiat singur în timpul indiviziunii cu privire la bunul comun sau cu privire la cota sa indiviză. De exemplu, fiecare coproprietar avea dreptul de a ipoteca partea sa ereditară şi chiar întreg bunul comun. El putea constitui ipotecă asupra cotei sale succesorale, grevând astfel toate bunurile succesorale. Sa presupunem că doi moştenitori A şi B deţineau două imobile, C şi D. Moştenitorul A a constituit ipotecă asupra cotei sale indivize de 1/2 din ambele imobile. La partaj, imobilul C este atribuit lui A, iar imobilul D este atribuit lui B. În continuare, fiecare imobil rămâne grevat de dreptul de ipotecă constituit de moştenitorul

7 A. Broussard, op.cit., pp. 23-24. Vânzătorul avea la îndemână acțiunea praescriptis verbis iar permutantul avea la dispoziție acțiunea ex empto. Partajantul putea uza de acțiunea ex stipulatu.

${ }^{8}$ A. Broussard, op.cit., p. 28. 
A asupra cotei de $1 / 2^{9}$. In sistemul efectului translativ, ipoteca se menținea asupra cotei-părți ipotecate de un partajant asupra bunului sau bunurilor succesorale şi după partaj, indiferent cărui partajant îi era atribuit lotul, deşi acesta nu consimțise la ipotecă, căci ipoteca nu se stingea odată cu înstrăinarea bunului (cotei indivize din bun) ${ }^{10}$. Partajantul care primea în lot bunul ipotecat avea să fie urmărit de către creditor şi, urmare pierderii bunului, s-ar fi îndreptat cu o acțiune în garanție împotriva partajantului care consimțise ipoteca. Or, aceste acțiuni judecătoreşti trebuia să fie evitate, căci provocau o gravă incertitudine, fragilizând partajul. Interesul terţilor era asigurat, dar securitatea partajelor era grav amenințată. Prețul menținerii drepturilor terţilor constituia o amenințare adusă liniştii familiilor. Romanii încercaseră diferite metode pentru a remedia aceste inconveniente ${ }^{11}$. De exemplu, jurisconsultul Iulian exprima opinia că judecătorul, atunci când atribuia unui partajant un bun grevat de o ipotecă consimțită de un alt partajant, ar fi putut să subevalueze bunul în considerarea posibilei evicțiuni ce ar fi urmat. Apoi, într-o lege din Digeste se indica o altă metodă pentru a preveni aceste inconveniente. Doi frați, A şi B dețin în coproprietate un fond. A constituie ipotecă asupra unei cote de 1/2 din fond în favoarea unui terţ. La partaj, fondul este împărțit în două părți egale, care sunt atribuite lui A şi B. Pentru ca B să aibă o garanție eficace în caz de evicțiune ar fi putut să-i pretindă lui A să-i constituie ipotecă asupra cotei de 1/2 din partea acestuia primită la partaj. Prima ipotecă greva jumătatea deținută de A înainte de

${ }^{9}$ Soluția era aceeaşi şi când A ar fi constituit un drept de uzufruct.

10 A. Broussard, op.cit., p. 32. Situația era şi mai gravă în dreptul roman, unde ipotecile erau oculte, iar partajanții se puteau aştepta oricând să se confrunte cu un creditor ipotecar al unuia dintre ei.

${ }^{11}$ A. Broussard, op.cit., pp. 33-34. 
partaj, iar a doua ipotecă ar fi grevat jumătatea primită de A prin partaj de la B. Cea mai mare problemă o constituia însă faptul că la Roma ipotecile erau oculte, iar acțiunile creditorilor luau mereu prin surprindere pe partajanți, căci aceştia nu aveau cunoştință de ipoteci.

Încă din perioada romană a existat şi o opinie izolată - o tentativă de revedere a efectelor partajului în favoarea coproprietarilor - care a constituit germenele efectului declarativ al partajului, care avea să survină câteva secole mai târziu. Într-o cauză, doi coproprietari stăpâneau în indiviziune un fond. La decesul unuia dintre coproprietari, acesta a lăsat uzufructul cotei sale indivize din fond în favoarea soției. La partaj, fondul împărțindu-se în două părți egale, s-a pus problema care este porțiunea grevată de uzufruct. Fïnd consultat în această privință, cunoscutul jurisconsult Trebatius a afirmat că uzufructul soției ar trebui să poarte numai asupra părții din fond atribuită moştenitorului coproprietarului decedat, nu şi asupra părții din fond atribuită celuilalt coproprietar. Opinia sa reprezenta tocmai germenele efectului declarativ al partajului. La acel moment, opinia sa a fost considerată o erezie de către discipolul său, Labeon, deoarece contrazicea teoria romană a efectului translativ: dacă uzufructul grevase o cotă din întreg fondul, atunci el trebuia să subziste la partaj şi asupra celeilalte părți atribuite coproprietarului. Opinia lui Trebatius - deşi a rămas înscrisă în Digeste - a fost unanim respinsă de contemporanii săi. Timpul efectului declarativ al partajului nu sosise încă ${ }^{12}$.

\footnotetext{
${ }^{12}$ St. Liégeard, op.cit., p.9; A. Broussard, op.cit., p. 46.
}

\section{5}




\section{Epoca feudală franceză}

Principiile dreptului roman au fost preluate apoi în dreptul feudal francez, în țările de drept scris. Abia în Franța cutumiară s-a dezvoltat treptat principiul efectului declarativ al partajului.

Între glosatori existau însă divergențe. Unii considerau că partajul era o vânzare, alţii că acesta ar fi fost un schimb. Inclusiv jurisconsultul Dumoulin considera - într-o manieră indecisă - că partajul are o natură mixtă ${ }^{13}$. Cu toate acestea, disputa părea a fi fără miză. Lăsând la o parte faptul că, la origine, vânzarea se confundă cu schimbul, în doctrină se arăta că cele două opinii puteau fi consiliate: astfel, partajul putea fi un schimb - în cazul partajului în natură, putea fi o vânzare - în cazul licitației - şi putea fi atât un schimb, cât şi o vânzare - în cazul partajului cu sultăă ${ }^{14}$.

În dreptul feudal francez, orice pământ avea doi stăpâni - seniorul şi vasalul - legați între ei prin obligații reciproce. Niciunul dintre ei nu putea ceda drepturile sale unui terț fără consimțământul celuilalt. În secolul al IXlea, a fost acordat pentru prima dată un drept de moştenire rudelor vasalului având ca obiect terenurile deținute de acesta. Această transmisiune trebuia însă însoțită de însezinare şi, implicit, de plata tributului către senior. Printro interpretare intenționat eronată a legilor romane, legiştii epocii au reuşit să fundamenteze transmiterea posesiei bunurilor către moştenitori - în temeiul celebrei maxime Le mort saisit le vif - fără plata tributului către senior. Aceasta a constituit prima victorie împotrive fiscalității feudale ${ }^{15}$. Dar, imediat s-a pus întrebarea dacă moştenitorii vasalului puteau proceda la partaj fără

\footnotetext{
13 St. Liégeard, op.cit., p. 6.

14 St. Liégeard, op.cit., p. 7.

15 St. Liégeard, op.cit., p. 23.
} 
acordul seniorului. $\mathrm{Cu}$ alte cuvinte, interdicția de a înstrăina terenul numai de unul dintre cei doi stăpâni, cuprindea şi interdicția moştenitorilor vasalului de a-l partaja fără acordul seniorului? Potrivit dreptului roman, răspunsul nu putea fi decât afirmativ. Numai că în acea epocă, jurisprudența romană căzuse demult în uitare, astfel încât judecătorii epocii considerau partajul o consecință a dreptului de moştenire, autorizându-l fără acordul seniorului. Dar nici seniorii nu erau dispuşi să cedeze uşor din autoritatea asupra vasalilor, astfel încât, în curând au interzis partajul fără acordul lor. Cutumele feudale au admis, într-un final, partajul succesoral fără acordul seniorului. Orice alt partaj, însă, nu putea fi făcut fără consimțământul seniorului. Cu timpul, instituțiile feudale s-au schimbat. Războaiele dintre seniori erau din ce în ce mai puține. Tributul militar pe care trebuia să-l plătească vasalul seniorului rămânea fără suport. Iar pe seniori nici nu-i mai interesa, în mod deosebit, persoana vasalilor lor. Dar, seniorii trebuia să obțină în continuare avantaje din relația senior-vasal. Astfel, atunci când vasalul voia să înstrăineze terenul, acordul seniorului era dat în schimbul unei sume de bani pe care vasalul o plătea seniorului. Se punea problema dacă şi moştenitorii vasalului trebuia să plătească seniorului această taxă. Dat fiind faptul că partajul - în buna tradiție romană avea efect translativ -răspunsul nu putea fi decât afirmativ. Numai că tot legiştii epocii - sub influența şcolii italiene - au afirmat că partajul cuprinde în sine o înstrăinare specială, adică una „forțată”, necesară pentru a ieşi din indiviziune. Consecința trebuia să fie scutirea de plata taxelor fiscale ${ }^{16}$. În acel moment, au luat naştere două curente diferite, care urmăreau însă acelaşi scop: eliminarea taxelor fiscale în cazul partajului. O parte dintre juriconsulți admiteau caracterul translativ al partajului, dar

\footnotetext{
${ }^{16}$ St. Liégeard, op.cit., p. 29.
} 
considerau că acesta reprezintă mai degrabă o înstrăinare „necesară”, scutindu-l astfel de plata taxele fiscale. $\mathrm{O}$ altă parte dintre jurisconsulți considerau - pur şi simplu - că partajul nu cuprindea o înstrăinare, acesta fiind adevăratul motiv pentru care nu se datorau taxele fiscale. Iar argumentarea acestora din urmă era una deosebit de subtilă. Dacă succesibilii unei persoane decid să renunțe la succesiune, lăsând acceptant numai pe unul dintre moştenitori, acesta moşteneşte întreaga avere nu în favoarea vreunui drept de acrescrământ, ci mai degrabă ca urmare a desesizării celorlalți succesibili. Dacă toți moştenitorii acceptă, atunci ceea ce le revine la partaj nu poate fi în temeiul unei achiziții, căci nu-ți poți achiziționa propriul bun. Are loc o pretinsă renunțare - şi nu o transmisiune - din partea unor moştenitori acceptanți care, fără îndoială, constituie o ficţiune. Pe fundamentul acestei ficțiuni se va dezvolta ulterior efectul declarativ al partajului.

Mijlocul secolului al XVI-lea a constituit momentul decisiv pentru tranşarea controverselor în ceea ce priveşte efectele partajului. Celebrul jurisconsult Dumoulin a jucat rolul principal în această controversă ${ }^{17}$. În luna noiembrie a anului 1538 următoarea speță a fost supusă analizei avocaților, printre care se afla şi Dumoulin. Patru frați dețineau un imobil în indiviziune succesorală. Cel mai mare avea cota de $1 / 2$, iar ceilalți trei aveau fiecare o cotă de 1/6 (1/3 din cealaltă jumătate). Seniorul a început urmărirea silită asupra unei cote de $1 / 6$ din imobil, care aparținea unuia dintre frați, pe care acesta nu-l agrea. În acel moment, frații au procedat la partaj. Întreg imobilul a fost atribuit fratelui cel mai mare. Fratele asupra cotei căruia se pornise urmărirea silită a primit un alt imobil, care depindea de alt senior. Se punea întrebarea

${ }^{17}$ A. Broussard, op.cit., pp. 54-56. 
dacă urmărirea silită începută asupra cotei de 1/6 înceta, dat fiind faptul că imobilul fusese atribuit în întregime fratelui mai mare. Potrivit principiilor dreptului roman, nu era nicio îndoială că urmărirea silită trebuia să continuie asupra părții de 1/6 din imobil, chiar dacă acesta fusese atribuit integral fratelui mai mare. Cu toate acestea, avocații au decis contrariul, iar urmărirea silită a fost desființată. Urmărirea silită ar fi putut continua numai dacă fratelui urmărit i-ar fi fost atribuită o parte din imobil şi numai asupra acestuia. Jurisconsultul Dumoulin era bolnav în acea perioadă şi lucra la unul dintre tratatele sale. Decizia l-a şocat. În opinia sa, folosind argumentele date de principiile dreptului roman, urmărirea silită a seniorului ar fi trebuit să continuie şi după partaj. Indiferent că imobilul era atribuit fratelui urmărit sau altui frate sau era împărțit, urmărirea silită începută asupra cotei de 1/6 nici nu se putea mări, nici nu se putea micşora şi trebuia menținută corespunzător. Fiind o acțiune reală, care nu avea legătură cu persoana, trebuia să continuie. Dumoulin s-a opus cu înverşunare admiterii noului efect al partajului. Adevărul e că, atât timp cât fusese vorba de a lupta contra drepturilor fiscale ale seniorului, Dumoulin fusese de acord cu oamenii palatului, pliind principiile romane pe propriile opinii. Acum însă nu putea concepe ca o ipotecă sau o urmărire silită să înceteze urmare a partajului. Una era pierderea drepturilor de către senior - cu care fusese de acord - şi alta era pierderea drepturilor de către un burghez sau un industriaş. Dumoulin însuşi era un burghez care avea ipoteci, pe care le voia menținute. Lupta sa era sortită eşecului. Jurisprundeța Parlamentului din Paris era net favorabilă noului curent care susținea efectul declarativ al partajului. Începând din 1569 până în 1595, patru hotărâri au admis efectul declarativ al partajului. Ficțiunea efectului declarativ a fost consacrată în anul 1580 în Cutuma Parisului în pofida opoziției jurisconsultului Dumoulin. Spre sfârşitul vieții, 
Dumoulin a revenit asupra opiniei sale. A admis faptul că partajul produce un efect retroactiv încă din ziua deschiderii succesiunii, că moștenitorul nu primeşte nimic de la comoştenitorii săi şi că, la rândul său, nu le transmite nimic, iar partajul nu face altceva decât să determine, să declare bunurile care au aparținut fiecărui moştenitor încă de la data deschiderii succesiunii. De aici, s-a născut maxima care afirmă că partajul este declarativ de proprietate. Jurisconsulții (Lebrun, Pothier) care i-au urmat nu au făcut altceva decât să preia principiul şi să-l includă în propriile lucrări, fără să-l conteste. Mai mult, au insistat asupra avantajelor efectului declarativ.

Din aceste motive, în doctrină s-a afirmat că efectul declarativ nu este un veritabil principiu juridic, ci, mai degrabă, o regulă de conjunctură. Este o ficțiune instituită de legiuitor pentru a favoriza partajele.

\section{Codul civil Napoleon}

În acest stadiu au găsit redactorii Codului civil Napoleon materia partajului în vechiul drept francez. Bineînțeles că temerile şi lupta contra seniorilor din perioada feudală nu mai existau. N-ar mai fi existat niciun motiv pentru a menține principiul efectului declarativ al partajului. Legiuitorul francez de la 1804 se afla în fața unei alegeri: putea reveni la principiile dreptului roman, care consacrau efectul translativ sau putea consacra defintiv efectul declarativ imaginat de jurisprudența veche. Reînvierea efectului translativ ar fi însemnat însă începutul unui şir nesfârşit de litigii între partajanţi. Creditorul ipotecar ar fi urmărit silit bunul în mâinile partajantului, acesta s-ar fi îndreptat apoi împotriva copartajanților şi ar fi trebuit să suporte şi eventuala insolvabilitate a acestora. Consecințele erau dezastruoase. Legiuitorul voia să protejeze moştenitorul prudent şi econom şi pacea familiilor. Interesele terților a trebuit să fie sacrificate în favoarea 
interesului comun al partajanților, lăsând în seama terților riscul insolvabilității constituitorului ${ }^{18}$. Mai mult, se aprecia că în cazul partajului, nu putea fi vorba de un negoț între moştenitori. Deci, nici vânzare, nici schimb. Din acest moment, art.883 Cod civil Napoleon (art.786 Cod civil român de la 1864) a consacrat efectul declarativ al partajului, reluând aproape cuvânt cu cuvânt definiția dată de jurisconsultul Pothier: „Fiecare coerede este prezumat că a moştenit singur şi imediat toate bunurile care compun partea sa, sau care i-au căzut prin licitație, şi că n-a fost niciodată proprietar pe celelalte bunuri ale succesiunii".

\section{B. Consecinţele efectului declarativ al partajului}

Ficțiunea efectului declarativ nu constă în aceea că partajantul a succedat defunctului, căci acesta oricum deținea o cotă parte din bunurile succesorale de la defunct, ci că a succedat singur în ceea ce priveşte întreg bunul atribuit ${ }^{19}$. Între părți nu s-a produs nicio transmitere a cotelor-părți. Se observă cum consecințele efectului declarativ al partajului erau fundamental diferite de cele ale efectului translativ din dreptul roman. Astfel, dacă un coproprietar constituia ipotecă asupra unui bun comun sau asupra cotei-părți din bunul comun, iar bunul era atribuit în cadrul partajului unui alt coproprietar, ipoteca se desființa, pentru că cel care a constituit-o nu a fost niciodată proprietar (non domino). Iată cum s-a putut realiza stabilitatea partajului, din perspectiva moştenitorilor.

Fără îndoială că principiul efectului translativ este cel conform realităţii. Inclusiv legiuitorul o recunoaştea implicit - folosind sintagma „este

\footnotetext{
${ }^{18}$ A. Colin, H. Capitant, Cours elémentaire de droit civil français, Paris, Librairie Dalloz, ediția a IV-a, 1925, tom III, p. 501.

${ }^{19}$ V. Marcadé, Explication théorique et pratique du Code Napoléon, tom III, Paris, 1868, p 294.
}

\section{1}


prezumat" - atunci când instituia ficțiunea caracterului declarativ. Numai printr-o ficțiune puteau fi şterse efectele indiviziunii, ca şi cum aceasta nu ar fi existat niciodată. În puterea efectului declarativ, partajanții țin drepturile, în virtutea legii, chiar de la autorul succesiunii, în temeiul adagiului le mort saisit le vif ${ }^{20}$. În realitate însă trecerea de la proprietatea indiviză la proprietatea exclusivă nu putea fi realizată decât printr-un schimb. Unii autori ${ }^{21}$ au afirmat că garanția pentru evicțiune dintre copartajanți (art.884 Cod civil Napoleon, art.787 Vechiul cod civil) ar fi reprezentat tocmai devoalarea adevăratului efect al partajului, deoarece o astfel de garanție este specifică numai actelor translative. Ea a fost instituită în dreptul roman tocmai în considerarea inconvenientelor efectului translativ. Alți autori (Pothier) au susținut că garanția pentru evicțiune din materia partajului nu are aceeaşi sursă ca garanția pentru evicțiune din materia vânzării şi nu ar trebui asimilate, deoarece garanția pentru evicțiune din partea partajului urmăreşte un at scop: egalitatea dintre copartajanți. În orice caz, garanția pentru evicţiune din materia partajului nu ar putea fi interpretată ca „o recunoaştere virtuală" a efectului translativ.

La început, efectul declarativ a constituit o (simplă) armă împotriva fiscalităţii feudale. El a luat naştere mai degrabă prin forța armelor. Nu a necesitat explicații juridice. După ce a pătruns însă în dreptul civil, ficţiunea efectului declarativ a fost explicată cu greu de doctrina franceză.

Potrivit jurisconsultului Dumoulin - care a acceptat într-un final noua soluție - partajul nu reprezintă altceva decât o consolidare a părții fiecărui partajant, care are un drept anterior cu privire la aceasta. Apoi, Henrion de

\footnotetext{
${ }^{20}$ Când există un singur moştenitor, nu există nicio îndoială în această privință.

${ }^{21}$ St. Liégeard, op.cit., p. 46.
} 
Pausey considera că prin partaj nu se dobândeşte un bun, ci facultatea exclusivă de a-l folosi odată cu renunțările celorlalți coproprietari la bun. Lebrun a fundamentat efectul declarativ pe celebra maximă Le mort saisit le vif. Argumentul putea fi susținut în materia partajelor succesorale, dar era inaplicabil în cazul altor indiviziuni având ca izvor altă sursă.

Într-o opinie din secolul al XIX-lea, a renumitului profesor Demolombe, susţinută şi de alți autori (Louet şi Domat), partajul nu are nimic fictiv, indiviziunea fiind o proprietate sub condiția partajului. Fiecare moştenitor era, în acelaşi timp, proprietar sub condiție suspensivă asupra bunurilor care vor forma lotul său şi proprietar sub condiție rezolutorie asupra bunurilor care vor fi atribuite celorlalți moştenitori. Efectul retroactiv este, deci, cel specific îndeplinirii oricărei condiții ${ }^{22}$.

În opinia jurisconsultului Pothier, partajul nu este un act achizitiv, translativ, ci este un act determinativ, prin care se determină bunurile pe care fiecare partajant le-a moştenit chiar de la defunct, în temeiul cotei indivize deținute ${ }^{23}$. Partajul nu este o afacere de comerț sau de schimb între moştenitori, de aceea nu poate constitui o vânzare sau un schimb. Natura sa este diferită. Scopul partajului este de a determina ce se cuvine just - în afara oricărei idei de speculă - fiecărui moştenitor corespunzător cotei indivize deținute ${ }^{24}$.

Intenția legiuitorului a fost întotdeauna ca moştenitorii să succeadă singuri defunctului, fără să intre în indiviziune şi fără să fie nevoie de un

\footnotetext{
${ }^{22}$ A. Broussard, op.cit., p. 60. Este vorba de o condiție legală, inerentă dobândirii proprietății indivize, care nu poate fi înlăturată de moştenitori. De aceeaşi părere este şi Nicolae Titulescu, op.cit., p.126.

23 A. Broussard, op.cit., p. 61.

24 A. Broussard, op.cit., p. 87.
} 
partaj. De exemplu, a statuat aceasta în cazul creanțelor care se divid de drept. Partajul devine necesar tocmai pentru că legea nu are puterea de a împărți material bunurile mobile şi imobile succesorale, cum o face în cazul creanțelor. Dar, partajul nu este decât o necesitate de fapt, care nu poate împiedica pe moştenitori să fie proprietari asupra bunurilor împărțite în temeiul aceluiaşi titlu care le conferă şi titlul de proprietari ai creanțelor moştenite. Aşadar, partajul nu poate constitui cauza titlului bunurilor atribuite moştenitorilor, pentru că aceasta este o simplă operațiune materială. Partajul declară numai bunurile care aparțin fiecărui moştenitor. Indiviziunea este temporară. Ea acordă, ce-i drept, un drept indiviz fiecărui moştenitor, dar aceasta tocmai din cauza imposibilității legii de a face ea însăşi împărțeala la momentul deschiderii succesiunii. Şi atunci se explică faptul că legea nu ţine cont de existența indiviziunii în cazul efectului declarativ, pentru că aceasta este esențialmente tranzitorie. Dar, indiviziunea rămâne totuşi un fapt pe care numai legea prin puterea ei îl poate şterge retroactiv. Ficțiunea ieşea în evidență mai ales în cazul licitației bunului în favoarea unui coproprietar sau al partajului cu sultă. Partajul cu sultă reprezintă o veritabilă vânzare până la concurența sultei. Sulta reprezintă în acest caz prețul pe care un partajant îl plăteşte pentru partea din bunurile succesorale care depăşeşte ce i s-ar fi cuvenit. În mod cert, nu putea avea drept la această parte în calitate de moştenitor şi atunci cu ce titlu o primeşte? Nu poate fi decât cumpărarea.

O altă problemă care s-a spus în doctrină până în secolul al XIX-lea era dacă bunurile atribuite partajantului în cadrul unei licitații erau proprii în totalitate sau numai corespunzător părții sale ereditare? Jurisconsultul Ferriere susținea această ultimă opinie, în timp ce Pothier considera că bunurile sunt în totalitate proprii, opinia sa fiind consacrată de art.883 Cod Napoleon (art.786 Cod civil de la 1865). Şi partajul cu sultă era tot un partaj 
declarativ, pentru că legiuitorul nu distingea ${ }^{25}$. Sulta, indiferent că era plătită din bunurile ereditare sau că era plătită din fondurile proprii ale partajantului, era bun propriu al partajantului care o primea, căci, în virtutea caracterului declarativ al partajului se considera că o ținea direct de la defunct. Cum nici debitorul sultei nu era considerat un cumpărător al părții care depăşea porțiunea sa ereditară, nici creditorul sultei nu putea fi considerat un vânzător al acestei părți, de unde rezultă că va primi sulta în calitate de moştenitor, iar dacă era căsătorit sub un regim matrimonial comunitar, sulta constituia bunul său propriu, dobândit prin succesiune ${ }^{26}$. Raționamentul era susținut expres de legiuitorul francez în art.1408 Cod Napoleon, potrivit căruia bunul imobil dobândit în timpul căsătoriei de către unul dintre soți care era coproprietar al bunului, în urma unei licitații sau în alt mod, nu constituia bun comun, ci bun propriu al soțului, acesta urmând să despăgubească comunitatea corespunzător sumei de bani folosită. Întregul raționament era fictiv, căci nu corespundea realității - porțiunea din bun dobândită în timpul căsătoriei peste ce i se cuvenea în temeiul cotei indivize ar fi trebuit să constituie bun comun - dar cum ficțiunea efectului declarativ fusese stabilită de legiuitor, interpretarea acesteia trebuia dusă până la capăt.

\section{Efectul declarativ şi efectul retroactiv al partajului}

La începutul secolului al XX-lea, doctrina franceză a aprofundat efectele partajului şi a considerat că trebuie făcută o distincție între efectul declarativ şi efectul retroactiv.

25 F. Laurent, op.cit., tom X, p. 416.

26 Problema se punea în dreptul românesc după adoptarea Codului familiei şi a regimului comunității legale. 
În concepția clasică, autorii considerau că efectul declarativ implică, în mod necesar, retroactivitatea partajului. Practic, cele două noțiuni erau, oarecum, confundate. Or, la începutul secolului al XX-lea, unii autori au observat că efectul declarativ nu implică retroactivitatea partajului. Dimpotrivă. Se poate menține efectul declarativ, renunțându-se la caracterul retroactiv al partajului, printr-o organizare a indiviziunii succesorale. Astfel, caracterul declarativ şi caracterul retroactiv sunt două noțiuni distincte. Prima nu o implică, în mod necesar, pe cea de-a doua. Iar, în timp ce efectul declarativ este de natura partajului, retroactivitatea reprezintă, fără îndoială, o ficțiune, un artificiu al legiuitorului. S-a afirmat şi că actul declarativ permite unui drept preexistent - dar, ineficace - să-şi producă efectele depline, el nu transformă niciun drept, ci dă eficacitate acestui drept. Pentru unii, faptul că partajul este un act declarativ prin esența sa, adică moştenitorul ține drepturile de la defunct, constituie o realitate psihologică ! Efectul declarativ presupunea două consecințe: una negativă - partajul nu operează un transfer al proprietății şi una pozitivă - partajul determină partea care i se cuvine fiecărui partajant.

$\mathrm{Au}$ existat şi autori care au negat inclusiv efectul declarativ al partajului. În concepția acestora (J. Chevallier, La Balle, Veronne), partajul nu are nici efect declarativ, dar nici efect translativ. Partajul este atributiv, determinativ sau lichidativ ${ }^{27}$.

${ }^{27}$ P. Raynaud, op.cit., pp. 855-863. 


\section{Actele asimilate partajului în sistemul efectului declarativ}

O altă dificultate consta în a şti căror acte li se aplică principiul efectului declarativ ${ }^{28}$. Bineînțeles, el se aplica în cazul partajului propriu-zis. Efectul declarativ este legat de noțiunea de împărțeală. Dar, practica mai cunoştea o multitudine de alte operațiuni cu titlu oneros (schimburi, tranzacții, etc) prin care moştenitorii ajungeau la aceleaşi rezultate ca ale partajului, acestea fiind asimilate partajului propriu-zis în ceea ce priveşte efectul declarativ.

Astfel, era, în general admis în doctrina şi jurispurenţa franceze, că principiul efectului declarativ se aplica nu numai partajului propriu-zis, ci tututor actelor cu titlu oneros care aveau ca efect încetarea indiviziunii, fie că aveau ca obiect un bun succesoral singular, fie întreaga indiviziune succesorală ${ }^{29}$. De altfel, însuşi art.786 Cod civil arăta că principiul efectului declarativ se aplica nu numai partajului, ci şi licitației între moştenitori, adică a vânzării bunului succesoral către unul dintre aceştia.

În afară de partajul succesoral, efectul declarativ se aplica şi partajului oricărui alt bun deținut în indiviziune, cum ar fi partajul bunurilor comune realizat de foştii soți. Nu ar fi fost niciun motiv pentru ca efectul declarativ să fie restrâns numai la partajul succesoral, din moment ce una dintre intențiile legiuitorului atunci când a adoptat această ficțiune a fost de pune capăt evicțiunilor la care ar fi dat naştere efectul translativ.

De asemenea, nu fără ezitări din partea jurisprudenței franceze, s-a decis că efectul declarativ se aplica şi partajului voluntar unde indiviziunea se

28 M. Eliescu, Moştenirea şi devoluţiunea ei în dreptul RSR, Editura Academiei RSR, Bucureşti, 1966, pp. 288-292. Autorul reia, în general, soluțiile jurisprudenței franceze.

${ }^{29} \mathrm{G}$. Dutruc, Traité du partage de succession et des opérations et formalités qui s'y rattachent, Paris, 1855, p.47. 
restrângea, adică înceta numai cu privire la unul dintre partajanți, eliminând unul sau mai mulți partajanți recalcitranți sau care nu doareau să mai rămână în indiviziune, primindu-şi astfel bunurile succesorale care li se cuveneau. $\mathrm{Nu}$ există nicio regulă care să impună ca indiviziunea să înceteze cu privire la toți partajanții. Discuția era importantă, căci dacă un astfel de act nu constituia un partaj, ci o vânzare a coproprietarului care ieşea din indiviziune, atunci ar fi avut efect translativ, cu toate consecințele acestuia. Dar, dacă legiuitorul a imaginat ficțiunea efectului declarativ pentru a ocoli inconvenientele efectului translativ, atunci aceasta trebuia aplicată oricărui partaj, fără nicio distincție ${ }^{30}$.

Moştenitorii dispun de cea mai mare libertate pentru a decide ce act să încheie pentru a pune capăt indiviziunii, fie că este vorba de un partaj, fie că este vorba de o licitație, de un schimb sau de o tranzacție. În esență, pentru ca un act să fie asimilat partajului trebuie ca toți partajanții să participe la acesta. Nu este cazul unei vânzări, care poate avea loc între toți moştenitorii sau numai între unii dintre aceştia. Dacă la vânzare participă toți moştenitorii, atunci actul echivalează cu un partaj. Inclusiv vânzarea făcută de toți moştenitorii unuia dintre ei sau, invers, de unul dintre ei în favoarea tuturor celorlalți. Dacă vânzarea este făcută de un moştenitor numai în favoarea unuia sau unora dintre moştenitori, actul nu poate echivala cu un partaj. Ea are efect translativ şi nu declarativ. Distincția avea o justificare în aceea că o vânzare la care ar fi participat toți moştenitorii, avea scopul - asemenea partajului - de a regla interesele comune ale tuturor moştenitorilor, pe când o vânzare făcută

$3^{30}$ H. et L. Mazeaud, J. Mazeaud, Fr. Chabas, Leçons de droit civil. Successions-Liberalités, tom IV, vol.II, Montchrestien, 1999, ediția a 5-a de L. Leveneur, S. Leveneur, p.887; Contra, la sfârşitul secolului al XX-lea, T. Huc, Commentaire théorique et pratique du Code civil, tom V, Librairie Cotillon, Paris, 1893, p. 541. Autorul se sprjinea pe jurisprudența Casației franceze din acea perioadă. 
numai unuia dintre ei urmărea un simplu interes particular. Or, legiuitorul nu face abuz de ficțiuni, ci recurge la acestea numai atunci când sunt necesare ${ }^{31}$.

Se aplică efectul declarativ şi donației prin care un moştenitor donează unui alt comoştenitor cota sa indiviză dintr-un bun sau din toate bunurile succesorale? Este cert că prin acest act indiviziunea încetează cu privire la unul dintre moştenitori. Doctrina a răspuns negativ, argumentând că este de esența partajului ca fiecare coproprietar să primească bunuri succesorale sau echivalentul în bani corespunzător porţiunii ereditare. Dacă un comoştenitor nu primeşte nimic, atunci actul nu poate fi catalogat nici partaj, nici nu poate fi asimilat partajului. Donația, fiind valabilă, va avea efect translativ de drepturi, menținându-se astfel eventualele sarcini constituite de donator asupra bunului comun ${ }^{32}$.

Dacă moştenitorii au făcut un partaj definitiv, încetând indiviziunea, dar apoi se arată nemulţumiţi de împărţeală, şi convin o altă împărţeală, aceasta nu poate constitui partaj, ci o altă convenţie, căci la data acesteia, indiviziunea încetase deja 33 .

III. Viziunea legiuitorului din 2011

\section{A. Problema de rezolvat}

Inconvenientul cel mai mare al efectului declarativ îl constituia ştergerea drepturilor reale consimțite de un coproprietar cu privire la cota sa parte sau cu privire la bunul comun, dacă bunul nu îi era atribuit acestuia la

\footnotetext{
${ }^{31}$ F. Laurent, op.cit., tom X, p. 445.

${ }^{32}$ G. Dutruc, op.cit., p. 70; F. Laurent, op.cit., tom X, p. 435.

33 A. Broussard, op.cit., p. 91.
} 
partaj. Din acest punct de vedere, atitudinea generală ostilă față de indiviziune aproape că era de înțeles. Fără îndoială că această soluție fusese adoptată pentru a remedia tocmai anumite consecințe ale efectului translativ din dreptul roman. Dar, acesta era punctul unde legiuitorul trebuia să intervină, pentru că şi indiviziunea avea nevoie de o mână care să o ridice din dizgrația în care se afla de atâtea secole.

\section{B. Înlocuirea obiectului garanţiei}

Legiuitorul din 2011 a identificat corect problema şi a reglementat o subrogație reală cu titlu particular (art.682 Cod civil) - soluție găsită într-un caz particular de legiuitorul francez chiar în materia partajului, încă de la 1885 - care deschide noi perspective indiviziunii.

Efectul declarativ a constituit o palmă grea dată creditului. Unii autori considerau chiar că efectul declarativ constituia o atingere indirectă adusă dreptului de proprietate, deoarece împiedica moştenitorii să dispună în condițiile cele mai avantajoase de dreptul lor indiviz ${ }^{34}$. Din acest motiv, legiuitorul francez din secolul al XIX-lea a fost nevoit să intervină şi să instituie o excepție de la efectul declarativ al partajului în materie maritimă, ipotecile asupra navelor fiind menținute chiar dacă bunul era atribuit unei alte persoane decât partajantului constituitor ${ }^{35}$. În orice caz, creditorii ar fi acceptat cu greu - iar, în condițiile economice de azi, deloc - să primească în garanție o cotă indiviză dintr-un bun, iar apoi garanția să fie desființată - în

34 F. Laurent, op.cit., tom X, p. 418.

35 Legea din 10 iulie 1885 (art.17 - „Dans tous les cas de copropriété, par dérogation à l'art. 883 du Code civil, les hypothèques consenties durant l'indivision par un ou plusieurs des copropriétaires, sur une portion du navire, continuent à subsister après le partage ou la licitation.”). 
sistemul efectului declarativ - în urma atribuirii bunului altui partajant decât constituitorul. Găsim că această inovație a legiuitorului român va permite partajanţilor să dispună - cu adevărat, din punct de vedere economic - de cotele părți din bunurile indivize, prin constituirea de garanții, care apoi se vor menține asupra bunurilor ce li se vor atribui la partaj. Partajantul dispune acum de cota indiviză - prin constituirea de garanții - la fel cum ar fi dispus de bunul exclusiv care i-ar fi atribuit. Creditorii nu vor mai fi sacrificați în urma partajului. Garanțiile vor fi, în toate cazurile, menținute şi, după caz, strămutate.

Acum, garanțiile constituite de un coproprietar cu privire la cota sa indiviză sunt şi rămân valabile, indiferent de cui îi este atribuit bunul indiviz. Ele nu mai depind de soarta partajului. Creditorii se văd astfel protejați. Dar, şi partajanții. Căci fiecare partajant are dreptul să primească bunuri libere de sarcini. Soluția înlocuirii obiectului garanției este oarecum firească dacă privim partajul din perspectiva ideii înlocuirii cotei-părți cu dreptul de proprietate exclusiv.

Problema posibilității strămutării garanţiei se pusese şi sub imperiul efectului declarativ, în ipoteza în care bunul era adjudecat de un partajant, susținându-se că ipoteca n-ar trebui să se stingă, ci să greveze prețul primit de constituitor. Motivația consta în aceea că efectul retroactiv al partajului trebuie să privească numai pe partajanți, nu şi pe terți. Dreptul de urmărire ar fi încetat, dar nu şi dreptul de preferință al creditorului ipotecar. Cu toate acestea, doctrina a susținut că o astfel de înlocuire a obiectului ipotecii nu este posibilă, din moment ce însăşi ipoteca s-a desființat ${ }^{36}$. Pentru aceleaşi motive, credem că nici constituitorul şi creditorul nu ar fi putut conveni în contractul

${ }^{36}$ A. Broussard, op.cit., p. 137. 
de ipotecă o astfel de înlocuire. Din moment ce, sub imperiul efectului declarativ, partajantul căruia nu îi era atribuit bunul asupra căruia constituise ipoteca, era considerat un non domino, evident că şi ipoteca se desființa, nepunându-se problema menținerii acesteia şi a schimbării obiectului garanției.

Să presupunem, acum, că bunul asupra căruia constituitorul constituise o ipotecă (asupra unei cote indivize) este atribuit acestuia. Se pune întrebarea dacă ipoteca va greva tot bunul sau numai cota indiviză asupra căreia a fost constituită iniţial? Problema se punea şi sub imperiul efectului declarativ al partajului, iar Casația franceză decisese că obiectul ipotecii, fiind specializat, nu se putea extinde dincolo de ce consimțise coproprietarul să garanteze, adică cota indiviză din bun ${ }^{37}$. În acelaşi sens a decis şi legiuitorul din 2011. Potrivit art.2353 alin.1 C.civ., ipoteca constituită asupra cotei-părți se strămută asupra bunului atribuit, ,„̂nsă numai în limita valorii cotei-părți indivize”.

\section{Problema altor drepturi constituite de un partajant în timpul indiviziunii}

Ştim că fiecare coproprietar este liber să dispună de cota sa parte din bunul comun (art.634 alin.1 Cod civil) ${ }^{38}$. Pe perioada indiviziunii, el poate

\footnotetext{
37 A. Broussard, op.cit., p. 135. Legiuitorul francez din 2006 a decis contrariul. Potrivit art. 2414 alin. (3) Cod civil francez - „L'hypothèque d'une quote-part dans un ou plusieurs immeubles indivis ne conserve son effet que dans la mesure où l'indivisaire qui l'a consentie est, lors du partage, alloti du ou de ces immeubles indivis ; elle le conserve alors dans toute la mesure de cet allotissement sans être limitée à la quote-part qui appartenait à l'indivisaire qui l'a consentie ; lorsque l'immeuble est licité à un tiers, elle le conserve également si cet indivisaire est alloti du prix de la licitation."

38 Legiuitorul nu a adus niciun fel de limitări exprese ale acestui drept. Mai mult, coproprietatea poate avea ca obiect orice drept real principal (art. 645 C.civ.)
} 
constitui chiar dezmembrăminte ale dreptului de proprietate - de exemplu, un drept de uzufruct - având ca obiect cota sa indiviză din bunul comun 39 . Ce se va întâmpla cu aceste drepturi la momentul partajului? Legiuitorul din 2011 a omis să rezolve această chestiune. Dispoziția privind strămutarea garanțiilor (art.682) fiind de strictă interpretare, aceasta nu poate fi aplicată. Se va strămuta dreptul de uzufruct constituit inițial asupra cotei părți din bunurile succesorale asupra bunului atribuit partajantului constituitor? În bună logică, răspunsul ar trebui să fie afirmativ. Cum partajul produce o înlocuire, ni se pare că această strămutare urmează principiile oricărei subrogații reale cu titlu particular. De altfel, strămutarea garanțiilor este o aplicaţie a acestui principiu. Apoi, dacă legiuitorul şi-a pus problema strămutării garanţiilor, înseamnă că finalitatea acestei viziuni a fost ca bunurile atribuite partajanților neconstituitori ai garanțiilor să fie libere de sarcini. Acesta a constituit un principiu al partajului. În trecut, era rezolvat diferit, prin desființarea drepturilor reale în cazul în care bunurile erau atribuite altui partajant. În prezent, legiuitorul şi-a imaginat soluția înlocuirii obiectului garanției. Dreptul coproprietarului de a dispune liber de cota sa indiviză trebuie conciliat cu dreptul fiecărui coproprietar de a primi la partaj bunuri libere de sarcini. Nu este admisibil ca un coproprietar, constituind un drept de uzufruct asupra cotei sale indivize dintr-un bun sau mai multe bunuri, să aducă atingere dreptului de proprietate exclusivă al partajanților, astfel cum acesta

39 Potrivit art.1108 Codul Calimach, „fiecare părtaş poate neatârnat şi de sine să amaneteze, să legatarisească, sau într-un alt chip să înstrăineze după a sa plăcere dreapta sa parte sau folosurile ei, întrucât nu va jigni drepturile părtaşilor lui.” Facem precizarea că un coproprietar nu ar putea constitui un drept de servitute (de trecere, de exemplu) asupra cotei-părți, căci aceasta presupune identificarea, determinarea fondului aservit. Or, aceasta este incompatibil cu dreptul de coproprietate, care este un drept abstract, nefiind determinat material individual, ci purtând asupra bunului comun. 
se va naşte la momentul partajului. În final, răspunsul la această problemă va fi dat de jurisprudență.

\section{Problema modalităţilor care ar afecta dreptul de coproprietate}

Indiviziunea succesorală, atunci când are ca origine succesiunea legală, nu este aptă să fie afectată de modalități. Dar, dacă indiviziunea are ca efect succesiunea testamentară, iar drepturile de coproprietate ale unui legatar sau ale unor legatari sunt afectate de către modalități impuse de testator? Sau, să ne imaginăm o indiviziune convențională, unde dreptul de coproprietate al unuia dintre coproprietari este afectat de o modalitate sau de un drept de denunțare unilaterală (de exemplu, donația între soți, având ca obiect o cotă indiviză dintr-un bun propriu sau ipoteza în care un donator donează în indiviziune un bun stipulând o clauză de reîntoarcere convențională a bunului în cazul precedesului unuia sau altuia dintre donatari). Se va menține sau nu modalitatea care afecta dreptul de coproprietate după partaj? Suntem de părere că răspunsul nu poate fi decât afirmativ. Dreptul rezolubil sau anulabil al unuia dintre coproprietari nu se va şterge odată cu efectuarea partajului. Îndeplinirea condiției va atrage desființarea întregii împărțeli.

\section{E. Efectul constitutiv al partajului - o naştere sui generis şi o înlocuire}

Din perspectiva asigurării drepturilor dobândite de terți de la un coproprietar, se părea că legiuitorul din 2011 reuşise - prin soluția transpusă în art.682 C.civ. - să echilibreze partajul şi să facă mai atractivă indiviziunea. Mai era nevoie de vreo schimbare? Soluția înlocuirii obiectului garanției era 
pe deplin compatibilă şi cu ficțiunea efectului declarativ, aşa cum o arată şi legiuitorul francez din 2006 (art.2414 alin.3 C.civ. fr.). Cu toate acestea, legiuitorul român a mers şi mai departe şi a modificat radical însuşi efectul partajului.

Potrivit art.680 C.civ., fiecare coproprietar devine proprietarul exclusiv al bunurilor sau, după caz, al sumelor de bani ce i-au fost atribuite, numai cu începere de la data stabilită în actul de partaj, dar nu mai devreme de data încheierii actului, respectiv de data rămânerii definitive a hotărârii judecătoreşti.

Voința legiuitorului român din 2011 este evidentă în ceea ce priveşte eliminarea ficțiunii efectului declarativ al partajului. Dar, care sunt acum efectele partajului? S-a restabilit realitatea, adică efectul translativ din dreptul roman şi cele două strămutări ale proprietății: una de la defunct, alta de la moştenitori?

Doctrina s-a preocupat în mică măsură în legătură cu această chestiune, conturându-se, totuşi, două opinii, practica notarială fiind cea mai interesată în desluşirea acestei chestiuni. Se pare că miza acestei distincții o constituie interferențele noilor efecte ale partajului cu regimul matrimonial al partajantului la data partajului.

Într-o opinie, se afirmă că partajul are efect constitutivive, dreptul de proprietate exclusiv fiind rezultatul unei „situații juridice noi”. Opinia se întemeiază şi pe dispozițiile art.994 alin.1 Cod procedură civilă, potrivit cărora, hotărârea judecătorească de partaj are efect constitutiv.

\footnotetext{
${ }^{40}$ Fr. Deak, R. Popescu, Tratat de drept succesoral, Ediția a IV-a, Universul Juridic, Bucureşti, 2019, vol.III, p. 222; D. Lupulescu, Proprietatea comună, Editura Universul Juridic, 2013, p. 156; D. Chirică, Tratat de drept civil. Succesiunile şi liberalitățile. Ediția a 2 -a, Ed. Hamangiu, Bucureşti, 2017, pp. 498-499.
} 
Într-o altă opinie, se afirmă că partajul are efect translativ de drepturi ${ }^{41}$, iar sintagma „devine proprietar exclusiv (...) numai cu începere de la data stabilită în actul de partaj” trebuie interpretată nu ca dată a naşterii vreunei proprietăți exclusive, ci ca dată a dobândirii - în etape - a proprietății exclusive, ca urmare a dobândirii celorlalte cote părți de la copartajanți. De altfel, practica notarială pare că vede în partaj un act translativ de drepturi, un schimb. Aceasta se poate observa adesea şi din formulările existente în contractele de partaj, potrivit cărora partajantul căruia i se atribuie un bun în exclusivitate „preia” cotele părți ale celorlalți copartajanțít². De asemenea, şi în practica birourilor de cadastru şi publicitate imobiliară, tariful de publicitate imobiliară este perceput nu la valoarea întregului bun imobil atribuit partajantului, ci la valoarea cotelor-părți ale celorlalţi copartajanți care „le-au cedat” în favoarea partajantului devenit proprietar exclusiv, indiferent că o astfel de formulă este prevăzută expres sau nu în contractul de partaj sau în hotărârea judecătorească43.

În doctrină ${ }^{44}$, se mai susţine că în sistemul efectului constitutiv al partajului, moştenitorii țin drepturile „direct din actul de partaj”, iar între ei nu a avut loc nicio operațiune de schimb translativă. Aşadar, nu se pune problema ca partajantul să fie având cauză nici al defunctului, dar nici al celorlalți coproprietari.

${ }^{41}$ Fl.A. Baias, E. Chelaru, R. Constantinovici, I. Macovei (coord.), Noul Cod civil. Comentariu pe articole, Editura C.H. Beck, Bucureşti, 2012, p. 735; A.-A. Moise, Scurte consideraţii despre partajul voluntar în sistemul Noului cod civil, Revista Dreptul nr.11/2012, pp. 58-71.

42 Ideea are însă la bază doar argumente de oportunitate fiscală.

43 Bineînțeles că problema stabilirii unor tarife sau a unor sarcini fiscale nu trebuie să se raporteze neapărat la natura juridică a operațiunii, putându-se avea în vedere şi alte circumstanțe.

44 D. Chirică, op.cit., p. 499. 
Evident că este legitim să ne întrebăm cum a putut partajul, o simplă împărțeală, o determinare a dreptului indiviz, să dea naştere unui drept nou? Dacă moştenitorul ar fi moştenit singur, atunci ar fi fost succesorul defunctului şi ar fi ținut drepturile de la acesta. Numai dintr-o întâmplare, acesta s-a aflat în indiviziune: pentru că există mai mulţi moştenitori şi pentru că legiuitorul nu are puterea să dividă el însuşi toate bunurile şi drepturile succesorale, cum o face explicit în cazul creanțelor, care se şi pretează unei împărțeli facile legale.

În cazul efectului declarativ, ficțiunea consta în faptul că partajantul ținea întreg bunul de la defunct, ştergându-se perioada indiviziunii succesorale. Legiuitorul de la 1864 imaginase o singură „strămutare a proprietății”45, prin efectul acceptării succesiunii.

Legiuitorul din 2011 nu a spus, spre deosebire de cel de la 1864, că partajantul „a moştenit singur şi imediat” bunurile care compun lotul său (art.786 Vechiul cod civil). Legătura dintre defunct şi partajant era menţinută prin această formulă. În final, dobândirea era una de natură succesorală. Acum, pare-se că partajantul nu a moştenit nimic din bunurile atribuite, ci „a devenit” proprietar! Aşa să fie?

În ceea ce ne priveşte, credem că trebuie revăzute trăsăturile specifice ale partajului. Efectul declarativ a fost suprapus acestora, dar care sunt constantele partajului?

Marele jurist român, Dimitrie Alexandresco, afirma că împărțeala este „operația prin care fiecare coproprietar primeşte o parte determinată în locul

45 D. Alexandresco, Explicaţiunea teoretică şi practică a dreptului civil român în comparaţiune cu legile vechi şi cu principalele legislaţiuni străine, Bucureşti, Ateleriele grafice SOCEC \& Co. Societate anonimă, 1912, tom III, partea a II-a, p. 782. 
părții nedeterminate ce el are asupra lucrurilor posedate în comun"46. Un alt celebru jurist, Constantin Hamangiu definea împărțeala ca „operațiunea prin care coproprietarii, în scop de a individualiza drepturile lor respective de proprietate, înlocuiesc părțile indivize ce le aveau în bunurile comune prin părți distincte, compuse din bunuri determinate" 47 . Profesorul Fr. Deak definea împărțeala ca „operațiunea juridică care pune capăt stării de indiviziune (coproprietate prin împărțirea, în natură şi/sau prin echivalent, a bunurilor aflate în indiviziune, având ca efect înlocuirea cu efect retroactiv a cotei-părți ideale, indivize asupra acestora, cu drepturi exclusive ale fiecăruia dintre coindivizari asupra unor bunuri (valori) determinate în materialitatea lor." 48 Recent, despre partaj s-a spus că este o noțiune complexă. Este în acelaşi timp un act, o operațiune, un rezultat, o divizare şi o atribuire49.

Aşadar, partajul substituie drepturi exclusive unui drept colectiv. Menirea partajului este de a modifica, în primul rând, forma de exercitare a dreptului de proprietate: ieşirea dintr-o stare şi trecerea într-o altă stare. Apoi, se va modifica şi obiectul dreptului de proprietate. Fie că partajanții îşi atribuie bunuri (sau valori) distincte, fie că divid material bunurile, obiectul dreptului de proprietate exclusivă nu mai poate fi acelaşi cu obiectul dreptului de proprietate colectivă.

46 D. Alexandresco, op.cit., tom III, partea a II-a, p. 454.

47 C. Hamagiu, Tratat de drept civil român, Editura „NAŢIONAL $\breve{A ” ~ S . ~ C I O R N E I, ~ B u c u r e s ̧ t i, ~}$ 1928, vol. III, p. 512.

${ }^{48}$ Fr. Deak, op.cit., p. 551. Definiția este menținută şi în Fr. Deak, R. Popescu, op.cit., vol. III, p. 188, eliminându-se, evident, precizarea privind efectul retroactiv.

49 J. Molinier, Le partage en droit fiscal, teză pentru obținerea doctoratului prezentată la Universitatea din Bordeaux, Franța, la data de 10 decembrie 2016, publică la adresa https://tel.archives-ouvertes.fr/tel-01636053, p. 14. 
Dar, cum se produce această transformare? Dreptul de coproprietate conține însuşi dreptul fiecărui coproprietar de a cere - la partaj - să primească un bun în exclusivitate, corespunzător mărimii dreptului indiviz deținut. Partajul divide, împarte. Partajul este locul unde coproprietatea asupra unui bun sau asupra unei mase patrimoniale se preschimbă în proprietate exclusivă asupra unui bun individual determinat. Aşadar, în opinia noastră, partajul produce, mai degrabă, o înlocuire, decât o determinare. Obiectul partajului este de a înlocui o cotă-parte cu proprietatea exclusivă. Această transformare, această înlocuire a cotei-părți, este de esența partajului şi constituie tocmai particularitatea sa. Este de esența indiviziunii să se transforme - la un moment dat - în una sau mai multe proprietăți exclusive. Germenele proprietăţii exclusive a existat încă de la momentul naşterii indiviziunii şi făcea parte din dreptul de coproprietate.

Dar, nu înlocuirea este cea care necesită explicații. Ci, cum a putut lua naştere proprietatea exclusivă? Care este sursa acesteia? În ceea ce ne priveşte, considerăm că naşterea proprietăţii exclusive este una sui generis. O proprietate exclusivă care, într-adevăr, nu provine de la defunct. Dar, nu ia naştere nici prin transmisiuni reciproce între copartajanți. Mai degrabă, au loc renunțări simultane50 la dreptul de coproprietate ale tuturor coproprietarilor, în vederea stingerii acestei stări, pentru viitor, concomitent născându-se un drept de proprietate exclusiv, individual, al fiecărui partajant asupra fiecărui bun atribuit. Aşadar, mai degrabă „un schimb de renunțări”, decât un schimb de $\operatorname{cote}^{51}$. Coproprietatea trebuie să se stingă pentru a lua

50 Dacă raționăm că, în cauză, au loc renunțări simultane ale fiecărui moştenitor, atunci, evident, nu se pune problema vreunui efect translativ.

${ }^{51}$ În sensul că partajul presupune mai degrabă o dezinvestire a fiecărui coproprietar, decât o investire, Aubry et Rau, Cours de droit civil français d'après la méthode de Zachariae, Ediția a cincea, Paris, ILGJ, 1917, tom X, p.190, nota 1. 
naştere proprietatea exclusivă. Dar, coproprietatea se stinge ca urmare a voinței legii, nu ca urmare a unui schimb de cote care va avea ca rezultat o adiție, o dobândire a celorlalte cote de către fiecare partajant. Este o stingere pentru viitor reglată de lege imperativ. Avem, totuşi, imaginea unui drept de proprietate, care, în forma de exercitare colectivă, era afectat de un termen extinctiv şi în forma de exercitare individuală, era afectat de un termen suspensiv, al cărui obiect nu este determinat. Condiția - căreia i se descoperise un rol în sistemul efectului declarativ, constând în faptul atribuirii sau nu a bunului partajantului constituitor al ipotecii - nu are niciun rol în această ecuație. Ipoteca se va menține - în temeiul unei înlocuiri - în toate cazurile asupra bunului sau sumei de bani atribuite partajantului constituitor (art. 682 C.civ.).

Fiind vorba de o înlocuire, de o subrogație cu titlu particular, bunul atribuit prin partaj va avea aceeaşi natură juridică ca şi cota-parte deținută de partajant 52 . Nu este nevoie să recurgem la efectul declarativ (şi retroactiv) pentru a înţelege aceasta. Este o continuitate. Indiviziunea (succesorală, postmatrimonială sau de altă natură) nu este ştearsă, ci este continuată (recunoscându-i-se efectele actelor juridice încheiate legal de către un coproprietar) cu proprietatea exclusivă. Acest fapt se poate vedea cu claritate şi din analiza drepturilor creditorilor personali ai unui coprietar după partaj asupra bunurilor atribuite (art.678 alin.1 C.civ.).

\footnotetext{
52 Din această perspectivă, ni se pare că eventuala tarifare - în materia publicităţii imobiliare a înscrierii dreptului de proprietate dobândit prin partaj la valoarea acestuia sau la o parte din această valoare este neavenită. Partajantul nu a dobândit nimic nou. El a înlocuit un prim drept - care, deja, făcuse obiectul unei tarifări - cu un drept nou.
} 


\section{F. Natura juridică a bunurilor atribuite în cadrul partajului din perspectiva regimurilor matrimoniale comunitare}

În practică, s-a pus problema naturii juridice a bunurilor atribuite în cadrul partajului din perspectiva regimului matrimonial al partajantului căsătorit. Potrivit regulii generale, bunurile dobândite în timpul regimului comunității legale de oricare dintre soți sunt bunuri comune în devălmăşie ale soților (art.339 C.civ.). Problema nu se punea sub imperiul ficțiunii efectului declarativ, unde se considera că partajantul (căsătorit) deținea bunul de la defunct, de la data deschiderii succesiunii, acesta având regimul juridic al unui bun propriu (art.31 lit.b C.fam.).

Astfel, în sistemul efectului constitutiv, fiind vorba de o înlocuire, nu încape nicio îndoială că bunul atribuit moştenitorului căsătorit - la data partajului - sub un regim matrimonial comunitar, are natura juridică de bun propriu - asemenea cotei-părţi pe care o înlocuieşte - potrivit art.340 alin.1 lit.a şi g C.civ. 53

Ce vom decide în cazul partajului cu sultă? Acesta presupune că un partajant a primit mai mult decât i s-ar fi cuvenit potrivit cotei sale părți, iar pentru a se respecta principiul egalității dintre partajanți, acesta va trebui să le plătească copartajanților o sultă. Va intra în comunitate partea din bun care depăşeşte înlocuirea la care partajantul avea dreptul?

Acum, este interesant de observat care era opinia în această privință sub imperiul efectului declarativ, acolo unde partajul cu sultă era asimilat partajului fără sultă. Explicația consta în faptul că restabilirea egalității prin

53 Soluția este identică şi în cazul partajului unei coproprietăţi post matrimoniale, în temeiul art. 340 lit. g) C.civ. 
plata unei sulte era o necesitate a partajului, nu era atât voită de partajanți, cât impusă de natura bunurilor care se împărțeau ${ }^{54}$. Şi atunci, dacă atribuirea bunurilor nu se putea face obiectiv decât cu plata unor sulte nu exista niciun motiv să se refuze acestui partaj efectul declarativ, asemenea partajului în care bunurile puteau fi distribuite corespunzător cotelor indivize fără plata unor sulte. Partajanţii - chiar când îşi plătesc sulte - nu urmăresc să încheie o afacere, nu speculează. Este incorect să spunem despre sultă că ar fi echivalentă cu noțiunea de preț. Partajanții urmăresc, pur şi simplu, să evalueze corect bunurile, nu să obțină un câştig.

Regimurile matrimoniale comunitare au vocaţia de a absorbi în masa bunurilor comune orice bunuri care nu au caracterul de bunuri proprii. În esență, trebuie să fie vorba de achiziții sau de alte acte cu titlu oneros. Numai că partajul, fiind un act determinativ, se pare că nu poate fi încadrat lesne în clasificarea actelor juridice, cu titlu oneros sau cu titlu gratuit.

Într-o primă opinie - proprie susținătorilor efectului translativ al partajului -, s-ar putea susține că în cazul partajului cu sultă, natura juridică a bunului este mixtă: pentru valoarea cotei indivize pe care o înlocuieşte, partea din bunul atribuit constituie bun propriu, iar pentru valoarea care depăşeşte cota indiviză înlocuită - şi pentru care se plăteşte sultă, partea din bun cade în comunitate 5 . După cum spus, avem rezerve că sulta poate fi asimilată prețului. În cadrul partajului, ea are rolul de restabili egalitatea. Este adevărat că partajantul care a primit mai mult plăteşte o sultă celuilalt partajant, dar acesta nu achiziționează nimic de la copartajant, căci efectul partajului este constitutiv. Nici partajantul care plăteşte sulta, nu cumpără,

\footnotetext{
54 A. Broussard, op.cit., p. 74.

55 Autorii care susțin teza efectului translativ al partajului consideră că aceasta este soluția chiar şi în cazul partajului fără sultă, A.A. Moise, op.cit., p. 66.
} 
nici cel care o primeşte, nu vinde. De altfel, întreaga operațiune nu ar putea fi asimilată, nici juridic, nici faptic, unei vânzări, unei tranzacții. Partajul nu este partaj pentru o parte din bun şi vânzare pentru o altă parte. Natura contractului este unitară. Iar, efectul constitutiv vine să confirme aceasta.

Într-o altă opinie - în acord cu efectul constitutiv - pe care o propunem, natura juridică a bunului atribuit trebuie să fie unitară. Acesta va avea, în integralitate, natura juridică a cotei-părți pe care o înlocuiește. Constituirea dreptului de proprietate exclusivă nu poate fi scindată ${ }^{5}$. În acest punct, se văd consecințele lipsei unei definiții legale a partajului. Nu trebuie să neglijăm faptul că partajul este un act deosebit de frecvent întâlnit în viața familiilor. A supune partajul cu sultă incidenței unor reguli matrimoniale ar însemna o nouă lovitură adusă acestui act juridic şi, implicit, liniştii din familii. Ni se pare că trebuie să le recunoaşteam partajanților dreptul de a ieşi din indiviziune în ce modalitate doresc. Fie că împărțirea bunului sau bunurilor nu este obiectiv posibilă, fie că aceasta ar fi posibilă, dar ar implica inconveniente materiale sau economice, fie că, pur şi simplu, un partajant decide să primească numai sultă, partajanții au întreaga libertate să iasă din indiviziune în ce modalitate convin.

Dincolo de considerentele privind utilitatea socială a partajului, chestiunea este una tehnică. Atât timp cât constituirea este una unitară, este neavenit să o scindăm în partea din bun corespunzătoare cotei părți şi partea din bun care depăşeşte această valoare. Ce am putea spune despre partea din bun care depăşeşte valoarea cotei sale părţi? Cu ce titlu o primeşte? Căci şi aceasta i se cuvine tot în temeiul cotei sale părți. În mod cert, nefiind vorba de un act translativ, nu o primeşte de la copartajanți. Este tot o (aceeaşi)

56 Paradoxul face că s-ar trece dintr-o proprietate colectivă (între moştenitori) într-o altă proprietate colectivă, cel puțin parțial (între soți). 
constituire, produsă în temeiul legii. Căci, tocmai cota sa parte îi conferă vocația de a dobândi o proprietate exclusivă cel puțin egală cu valoarea acestei cote din bunul comun. Dacă legiuitorul nu ar fi permis aceasta, partajul ar fi fost aproape imposibil. Iar constituirea în cazul partajului - cu sau fără sultă - nu este una cu titlu oneros, căci scopul partajului a rămas, în continuare, de a determina. Sulta este necesară pentru a se reechilibra împărțeala. Dacă părțile nu încheie un act translativ, atunci nu poate fi vorba de o achiziție cu titlu oneros, care să intre sub incidența dispozițiilor art.339 C.civ.

Faptul plății sultei din fonduri comune ale soților va da naştere unei creanțe în favoarea celuilalt soț la data lichidării comunităţii. De altfel, obligația de plată a sultei (de a da) este o obligație proprie a partajantului căsătorit. El numai întrebuințează fonduri comune ale soților pentru a o executa. Dar aceasta nu poate afecta natura juridică a dreptului de proprietate dobândit, căci întreg raportul juridic la care a dat naştere partajul se situează pe tărâmul drepturilor şi obligațiilor proprii ale partajantului căsătorit.

Reiterăm ideea că partajul constituie un act deosebit de important pentru viaţa familiilor, ştiut fiind că indiviziunea succesorală este cea mai frecventă formă de coproprietate. Acest act a fost dintotdeauna privit cu favoare de legiuitor, în această privință, dovadă stând chiar instituirea ficţiunii efectului declarativ. $\mathrm{Nu}$ vedem niciun motiv pentru care efectele partajului ar trebui să se ciocnească, azi, atât de violent de normele regimurilor matrimoniale. Fără îndoială că există şi soluții: anterior partajului, partajantul căsătorit poate adopta regimul comunităţii convenționale, stipulând că bunurile dobândite printr-un partaj cu sultă sunt bunurile sale proprii. Dar, ni se pare că soluția trebuie să fie una mai simplă.

În concluzie, chiar şi sub imperiul efectului constitutiv, considerăm că în cazul partajului cu sultă, constituirea dreptului de proprietate „majorată” 
în favoarea unui partajant căsătorit se face tot în temeiul cotei-sale părţi, iar bunul astfel dobândit va avea, în integralitate, regimul juridic de bun propriu pe care l-a avut cota sa parte. 